\title{
Small-volume U-Pb zircon geochronology by laser ablation-multicollector-ICP-MS
}

\author{
Scott Johnston *, George Gehrels, Victor Valencia, Joaquin Ruiz \\ University of Arizona, Department of Geosciences, Gould-Simpson Bldg \#77, 1040 E 4th St., Tucson, AZ 85721, United States
}

\begin{abstract}
A B S T R A C T
$\mathrm{U}-\mathrm{Pb}$ zircon geochronology is hampered by problems acquiring meaningful geologic ages on zoned grains that retain isotope signatures from multiple growth or thermal events. We present a new method using laser ablation-multicollector-inductively coupled plasma-mass spectrometry to overcome complications associated with intricately zoned zircon crystals through in situ sampling of zircon volumes as small as $12-14 \mu \mathrm{m}$ in diameter by $4-5 \mu \mathrm{m}$ in depth ( $<3 \mathrm{ng}$ of zircon). Using Channeltron multipliers to monitor $\mathrm{Pb}$ intensities in conjunction with a total ion counting method and errors calculated as function of the number of counts, the small-volume technique reproduced published ages on eight Mesoproterozoic-Cretaceous secondary zircon standards precise and accurate within $2 \%$, and an age $\sim 1$ Ma too young on a Oligocene-aged grain. Two initial applications of the small-volume technique - the detrital zircon provenance of fine-grained mudstones and shales and the creation of zircon $\mathrm{U}-\mathrm{Pb}$ age maps to investigate the detrital and metamorphic history of a granulite-facies paragneiss - demonstrate the utility of this technique to a variety of geologic problems and confirm the viability of laser ablation-multicollector-inductively coupled plasma-mass spectrometry as a tool for high spatial resolution $\mathrm{U}-\mathrm{Pb}$ geochronology.
\end{abstract}

\section{Introduction}

$\mathrm{U}-\mathrm{Pb}$ zircon geochronology has become one of the most powerful techniques for obtaining absolute ages on a variety of hightemperature igneous and metamorphic events, as well as placing constraints on the timing and provenance of sedimentary processes. Zircon, in particular, has proven especially well suited for $\mathrm{U}-\mathrm{Pb}$ geochronology because of its relative abundance in a wide variety of rock types, its tendency to include $\mathrm{U}$ and exclude $\mathrm{Pb}$ from its crystal structure, and its resistance to physical and chemical weathering. In addition, zircon's high closure temperature to the diffusion of $\mathrm{Pb}$ allows single crystals to retain chemically distinct zones that record multiple growth or high-temperature Pb-loss events (Cherniak and Watson, 2003). While these complexly zoned crystals with inherited cores and younger rims - the product of either renewed crystal growth or Pb-loss - contain tremendous potential for unraveling complicated tectonic histories, these grains are analytically challenging because analysis of multiple domains can yields geologically meaningless ages that represent a mixture of multiple thermal events. Although the decay scheme of $U$, which includes two radiogenic isotopes with well-known decay constants, facilitates checks for the presence of mixed ages and a method for the deconvolution of multiple ages (Wetherill, 1956), the confidence in deconvolved older and younger ages is often poor. New research attempting to eliminate these problems with complexly zoned zircons takes advantage of recent improvements in the sensitivity and analytical capabilities of mass spectrometers by analyzing increasingly smaller samples, obtained by breaking individual crystals (e.g., Schmitz and Bowring, 2000) or using in situ techniques including ion beams (e.g., Vavra et al., 1996; Ireland and Williams, 2003) and laser ablation (e.g., Fryer et al., 1993; Kosler and Sylvester, 2003, Gehrels et al., 2008), to isolate and selectively sample parts of zircons that are characterized by single-age domains. Here, we present a new technique using laser ablation-multicollector-inductively coupled plasma-mass spectrometry (LA-MC-ICP-MS) at the Arizona LaserChron Center (University of Arizona) to sample and analyze $\mathrm{U}-\mathrm{Pb}$ isotopes from zircon volumes as small as $12-14 \mu \mathrm{m}$ in diameter by $4-5 \mu \mathrm{m}$ in depth $(<3 \mathrm{ng})$, and capable of rapidly producing ages with precision and accuracy $<2 \%$ (at $2 \sigma)$.

\section{Small-volume U-Pb method}

\subsection{Sample preparation}

Zircons are separated from bulk rock hand samples using standard rock pulverization followed by density and magnetic separation techniques. Separated zircons are then mounted with an external zircon standard in epoxy discs one inch in diameter; mounting unknown zircons and standards close to each other and in the inner $1 / 2$ inch of the mount minimizes $\mathrm{U}-\mathrm{Pb}$ fractionation related to spatial 


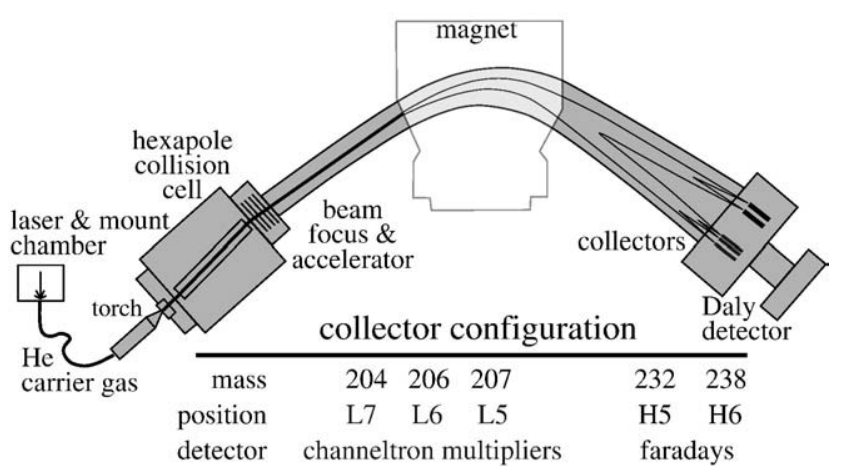

Fig. 1. Sketch diagram of the New Wave Instruments laser-GV Instruments Isoprobe at the Arizona LaserChron Center that illustrates the collector configuration used during small-volume U-Pb geochronology.

variation of carrier gas over the sample surface (Gehrels et al., 2008). Sample mounts are then sanded and polished $\sim 1 / 3$ of the way through unknown grains, carbon coated, and imaged on a SEM fitted with a cathodoluminescence $(\mathrm{CL})$ detector to characterize chemical zoning, qualitatively assess $U$ concentration, and identify core-rim relationships within unknown grains (Hanchar and Miller, 1993; Corfu et al., 2003; Nasdala et al., 2003). After CL imaging, the carbon coat and any associated common $\mathrm{Pb}$ is removed from the sample surface by lightly repolishing (removing the uppermost $\sim 1-2 \mu \mathrm{m}$ ) and ultrasonically washing the mount in a dilute acid $\left(1 \% \mathrm{HNO}_{3}+1 \% \mathrm{HCl}\right)$ solution.

\subsection{Data acquisition: laser and ICP-MS setup}

U-Pb analyses are performed at the Arizona LaserChron Center at the University of Arizona using a GV Instruments Isoprobe equipped with the S-option interface and coupled with a New Wave Instruments $193 \mathrm{~nm}$ ArF excimer laser (Fig. 1). During the 30-second data acquisition routine, zircons embedded in the sample mount are micro-sampled in situ using a laser operating with the beam diameter set to $10 \mu \mathrm{m}$ and a constant fluence of $\sim 4 \mathrm{~J} / \mathrm{cm}^{2}$ (Gehrels et al., 2008). Laser pits imaged and measured using a MicroXAM 3D profiler at the University of California,

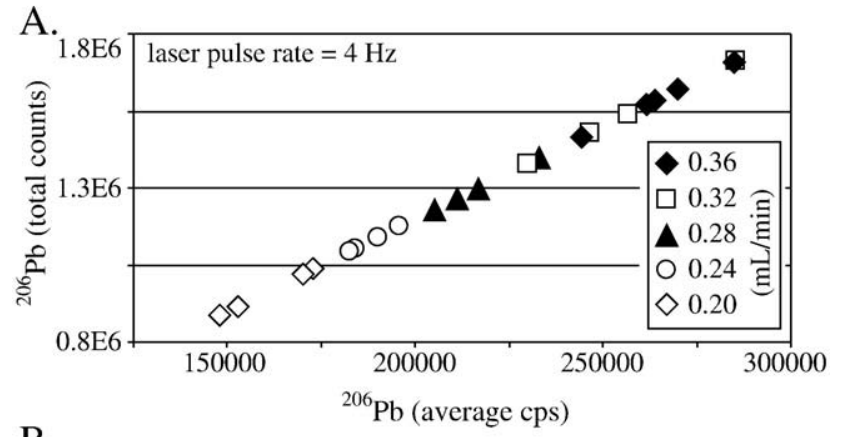

B.

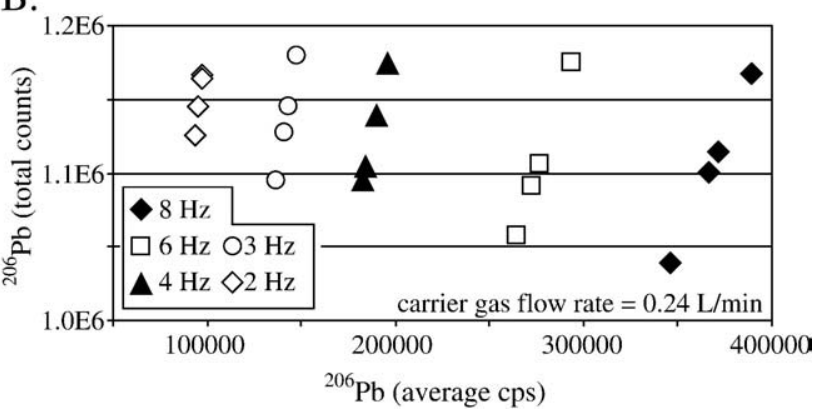

Fig. 3. The relationship between average counts per second and total integrated counts ${ }^{206} \mathrm{~Pb}$ on standard Sri Lanka Zircon using 24 laser pulses with variable A) carrier gas flow and $\mathrm{B}$ ) laser hit pulse rate.

Los Angeles indicate approximately cylindrical laser pits with openings of $12-14 \mu \mathrm{m}$ in diameter tapering to bases $8-10 \mu \mathrm{m}$ in diameter with $<1 \mu \mathrm{m}$ of floor relief (Fig. 2). Adjusting the total number of laser pulses from 32 to 40 resulted in pit depths of $4.0 \mu \mathrm{m}$ and $5.0 \mu \mathrm{m}$, respectively, yielding a constant ablation rate of $0.125 \mu \mathrm{m} /$ laser pulse $(0.5 \mu \mathrm{m} / \mathrm{second}$, Fig. 2) and a sample mass of $<3 \mathrm{ng}$. A series of tests were run on a single fragment of standard Sri Lanka Zircon (Gehrels et al., 2008) to optimize the laser pulse rate and the rate of He-Ar carrier gas (Günther and Heinrich, 1999) flowing over the sample surface (used to transport ablated material into the plasma). Holding the laser hit rate constant at $4 \mathrm{~Hz}$, increasing carrier gas flow from $0.2-0.36 \mathrm{~L} /$ min yielded a linearly
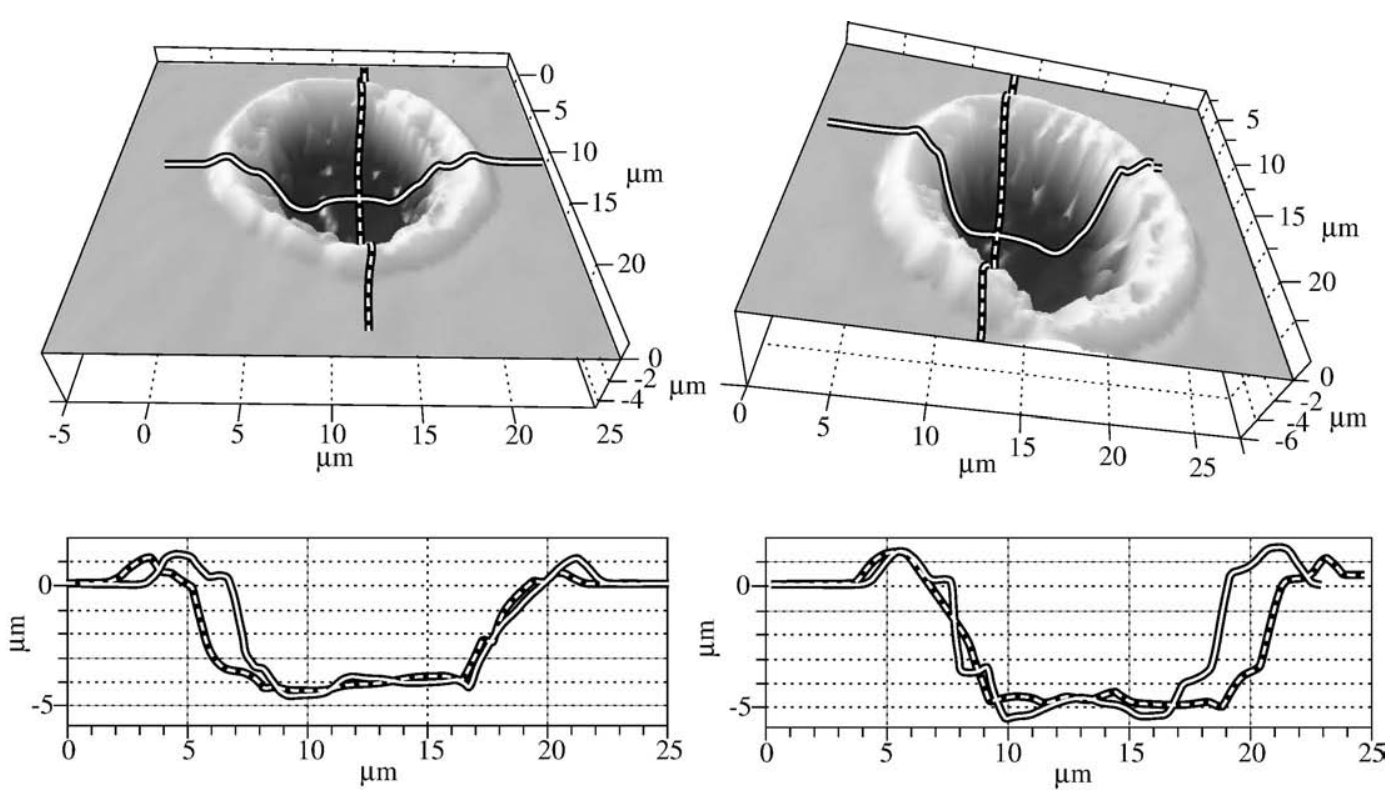

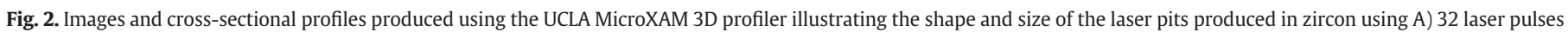
and B) 40 laser pulses. 


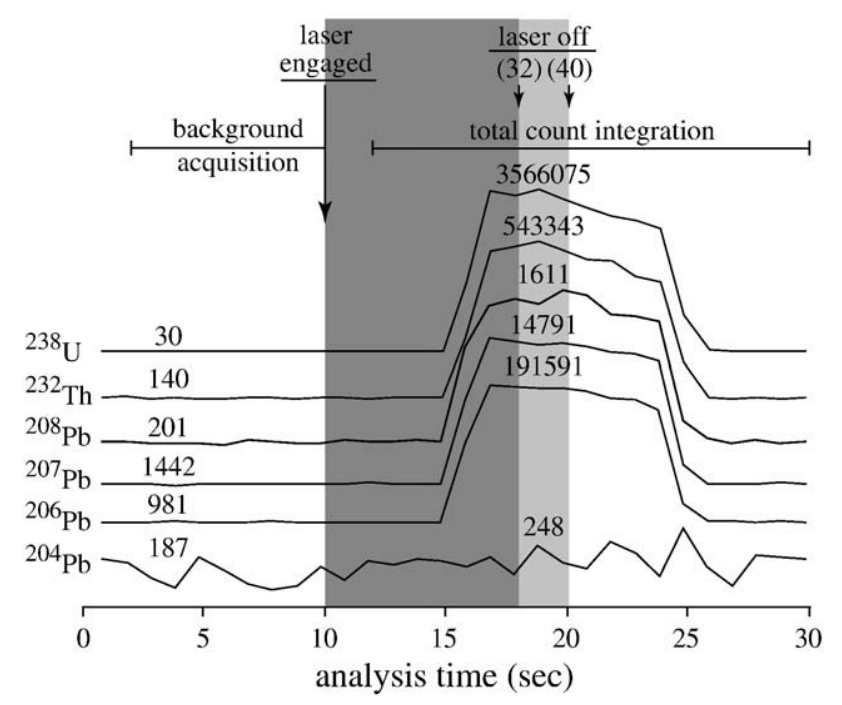

Fig. 4. Graph illustrating the relative timing of the background measurement, laser engagement, the total count integration of sample signal, and the corresponding isotope intensities over the course of a typical analysis. Grey boxes indicate the duration of the laser engagement for 32 pulses (dark grey) and 40 pulses (light grey). Average backgrounds and peak signal intensities are given in counts per second ( $100000 \mathrm{cps}=1 \mathrm{mV}$ ) from an analysis of Sri Lanka zircon during the February standard session (40 laser pulses at $4 \mathrm{~Hz}$ ).

increasing relationship between average counts per second and integrated total counts over the entire $30 \mathrm{~s}$ analysis (Fig. 3A, see data reduction and description of total counts technique below). This relationship may be related to either increased pit-extraction efficiency or greater elemental evaporation in the carrier gas at higher carrier gas flows. In contrast, while holding the carrier gas flow constant at $0.24 \mathrm{~L} / \mathrm{min}$, increasing laser pulse rate from 2 to $8 \mathrm{~Hz}$ yielded higher average counts per second, but total counts remained constant, although less scatter was observed at lower hit rates (Fig. 3B). Under normal operating conditions, the laser is set to pulse at $4 \mathrm{~Hz}$ with a carrier gas flow of $0.24 \mathrm{~L} / \mathrm{min}$ in order to minimize scatter and generate signal intensities best suited to the Isoprobe detectors from zircons with a range of $\mathrm{U}-\mathrm{Pb}$ concentrations, although both of these settings can be adjusted to accommodate samples with unusually high or low $\mathrm{Pb}$ isotope concentrations.

$\mathrm{U}-\mathrm{Pb}$ isotopes are counted on the Isoprobe using a 30-second acquisition routine that measures backgrounds followed by sample peaks in one-second integration periods. Background intensities are measured with the laser off for the initial $10 \mathrm{~s}$ of the analysis, after which, the laser is fired for $8-10 \mathrm{~s}$, the sample is introduced to the plasma, and sample signal is monitored for the remainder of the analysis routine. The sample signal arrives at the detectors $4-5 \mathrm{~s}$ after the laser is fired and washes out several seconds before the end of the 30 -second analysis (Fig. 4). The Isoprobe is operated with the intermediate gas at $1.0 \mathrm{~L} / \mathrm{min}$, the Ar coolant gas at $14.0 \mathrm{~L} / \mathrm{min}$, an $\mathrm{Ar}$ flow rate of $0.24 \mathrm{~mL} / \mathrm{min}$ through the hexapole collision cell, and with an accelerating voltage of $\sim 6 \mathrm{kV}$ (Gehrels et al., 2008). To thermally stabilize the plasma during analyses and thereby increase the sensitivity and the stability of the signal, analyses are run in a wet plasma created by continuously aspirating MilliQ water into the plasma using a microconcentric nebulizer with an uptake of $50 \mu \mathrm{L} / \mathrm{min}$ coupled with an Ar flow rate of $0.340 \mathrm{~L} / \mathrm{min}$ (Gehrels et al., 2008). At these operating conditions, approximate background levels (measured by scanning over the peaks using a Channeltron detector and depending on the particular analysis session) are approximately $300 \mathrm{cps}$ ${ }^{204} \mathrm{~Pb}+{ }^{204} \mathrm{Hg}, 1700 \mathrm{cps}{ }^{206} \mathrm{~Pb}, 2000 \mathrm{cps}{ }^{207} \mathrm{~Pb}, 140 \mathrm{cps}{ }^{232} \mathrm{Th}$ and $30 \mathrm{cps}$ ${ }^{238} \mathrm{U}$. With the laser activated at $4 \mathrm{~Hz}$ and ablating at $\sim 0.5 \mu \mathrm{m} / \mathrm{s}$, peak ion intensities on standard Sri Lanka zircon (563.5 Ma, 518 ppm U, $\sim 118 \mathrm{ppm} \mathrm{Th},{ }^{206} \mathrm{~Pb} /{ }^{204} \mathrm{~Pb}=\sim 16000$, Gehrels et al., 2008) are typically $<50$ cps above background on ${ }^{204} \mathrm{~Pb}, 190000 \mathrm{cps}{ }^{206} \mathrm{~Pb}, 15000 \mathrm{cps}{ }^{207} \mathrm{~Pb}$,
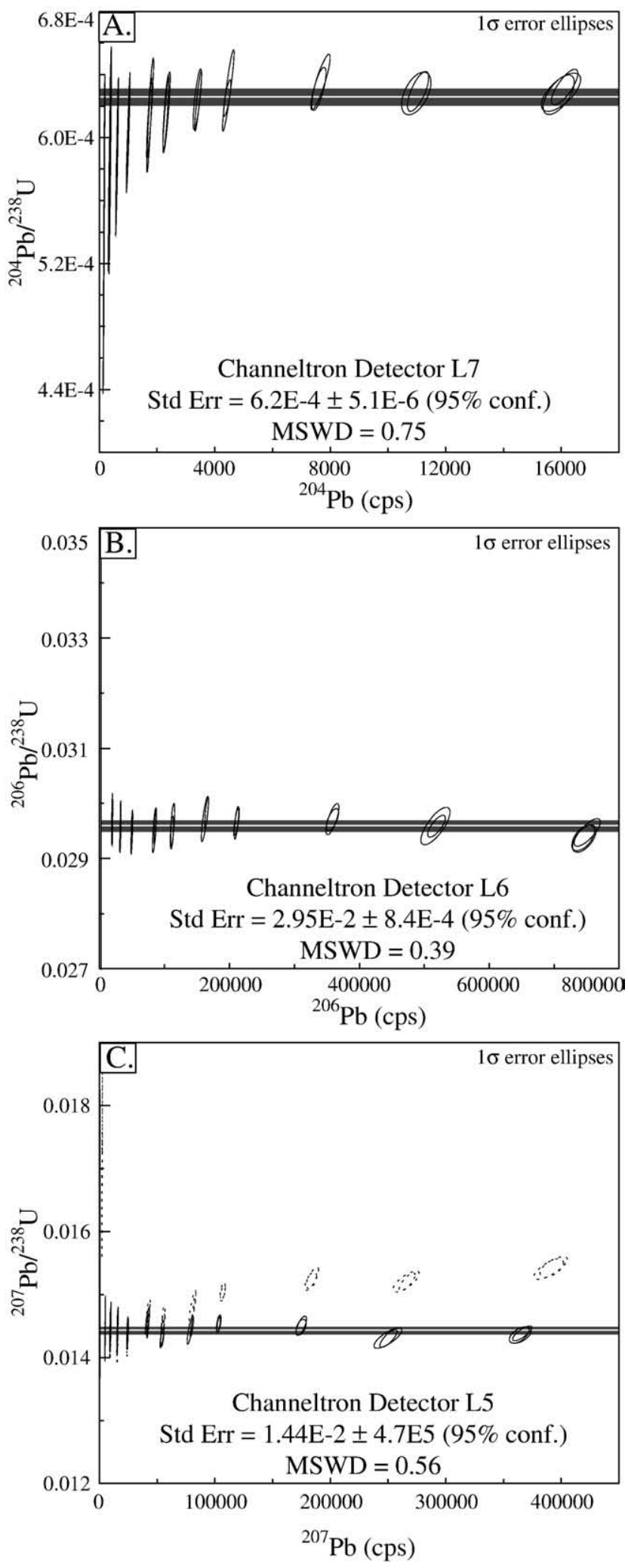

Fig. 5. Results from Channeltron linearity experiments comparing $\mathrm{Pb}$ signal variation (blank - corrected) on the channeltron detectors with respect to ${ }^{238} \mathrm{U}$ measured on faraday detector H6. White lines and grey areas indicate the weighted average of all analyses \pm 1 standard error. Dashed ellipses in C and D represent uncorrected values whereas solid ellipses represent corrected values. 
460000 cps ${ }^{232} \mathrm{Th}$ and $3500000 \mathrm{cps}{ }^{238} \mathrm{U}$; this translates to a $\mathrm{U}$ sensitivity of $\sim 6800 \mathrm{cps} / \mathrm{ppm} U$ (Fig. 4).

Low $\mathrm{Pb}$ isotope yields during small-volume $\mathrm{U}-\mathrm{Pb}$ analyses require that ${ }^{204} \mathrm{~Pb},{ }^{206} \mathrm{~Pb}$, and ${ }^{207} \mathrm{~Pb}$ are measured on low-side Channeltron electron multipliers, L7-L5, while ${ }^{232} \mathrm{Th}$ and ${ }^{238} \mathrm{U}$ are measured on high-side faraday detectors $\mathrm{H} 5$ and $\mathrm{H} 6$ with $10^{11} \mathrm{ohm}$ resistors (Fig. 1). Channeltron detectors are run in pulse-counting mode and are set to trip at $\sim 1 \times 10^{6}$ cps while faraday detectors can easily accommodate $1 \times 10^{8}$ cps. Channeltron linearity was checked using the detector geometry above and a dead time correction of zero ns for detector L7, and $20 \mathrm{~ns}$ for detectors L6 and L5, to analyze a radiogenically enriched U-Pb solution ( ${ }^{204} \mathrm{~Pb}:{ }^{206} \mathrm{~Pb}:{ }^{207} \mathrm{~Pb}:{ }^{238} \mathrm{U} \sim 1: 47: 23$ : 1600$)$ systematically diluted to produce the range of $\mathrm{Pb}$ signal intensities typically observed in zircon during laser analyses (Electronic Supplement, Table ES1A, B). Each solution was analyzed twice using a counting routine with 30 one-second integrations to calculate the mean and standard deviation on each peak. With respect to ${ }^{238} \mathrm{U}$, detectors $\mathrm{L} 7\left({ }^{204} \mathrm{~Pb}\right)$ and L6 $\left({ }^{206} \mathrm{~Pb}\right)$, were linear at the $95 \%$ confidence level to $1600 \mathrm{cps}$ and 750000 cps, respectively (Fig. 5A, B). Although there was a $14 \%$ decrease in the ${ }^{204} \mathrm{~Pb} /{ }^{238} \mathrm{U}$ at intensities $<4000$ cps and a $2-5 \%$ increase in ${ }^{204} \mathrm{~Pb} /{ }^{238} \mathrm{U}$ at intensities $<10000 \mathrm{cps}$, corrections were not made to these detectors because the measurements were within error of the mean. In contrast, detector $\mathrm{L} 5\left({ }^{207} \mathrm{~Pb}\right)$ records a $\sim 1 \%$ decrease in signal from $5000-25000$ cps followed by a gradual $8 \%$ increase in signal from 25000-400000 cps (Fig. 5C). This dip in signal intensity on the L5 detector is corrected offline using a visual-fit model that, with respect to ${ }^{238} \mathrm{U}$, yields linear relationships at the $95 \%$ confidence level to $400000 \mathrm{cps}$ (Fig. 5C). As the Channeltron detectors age with use and time, it will be essential to repeat these linearity experiments periodically to check linearity and recalibrate the correction models, if necessary.

\subsection{Data reduction: total count technique, error propagation and} fractionation

$\mathrm{U}-\mathrm{Pb}$ isotope data collected on the Isoprobe are reduced offline using an Excel macro and spreadsheet that calculates backgrounds and performs a total count analysis on the cumulative sample signal. Signals collected on the backgrounds during integrations 3-10 are used to calculate average background intensities, $n_{b g}$, and corresponding standard deviation, $\sigma_{b g}$ (normalized to the Student's $t$-distribution for 7 degrees of freedom), on each of the measured isotopes. For ${ }^{232} \mathrm{Th}$ and ${ }^{238} \mathrm{U}$, background levels are much less than the detection limits of the faraday detectors on which they are measured, and $n_{b g}$ and $\sigma_{b g}$ represent a measurement of the electronic baseline for each individual detector. In contrast to the relatively constant background signals, signal intensities produced on the sample cannot be used to calculate meaningful average signal intensities due to a number of factors including: 1) noise inherent to sample introduction through laser ablation, 2) decreasing down-pit extraction efficiency, 3) low signals that require longer counting integration periods of $1 \mathrm{~s}$, and 4 ) the short 8-10 s duration of the sample signal. To avoid this noise, signal intensities on the sample are reported as a total count integration, $N$, of the counts on the sample, $n_{s}$, minus $n_{b g}$, for analysis integrations 12-30 (Fig. 4):

$N=\sum_{t=12}^{t=30}\left(n_{s}-n_{b g}\right)$

In addition to eliminating errors associated with laser signal noise, another advantage of the total counts technique is that it eliminates the need to correct for $\mathrm{U}-\mathrm{Pb}$ fractionation associated with decreasing and variable down-pit extraction efficiency.

While the total count method successfully avoids errors associated with laser signal instability and down-pit extraction efficiency, it requires that sample errors are calculated as a function of the number of counts rather than the more traditional method of calculating the error on a series of isotope ratios. This relationship between count rate and error can be investigated using the linearity tests, which yield analytical errors derived over a broad range of concentrations and on all detectors, and suggest systematic but different error-count rate trends for Channeltron and faraday detectors. In contrast to a Poisson distribution with error equal to root $n$ - commonly assumed for counts of large numbers - the linearity tests indicate that Channeltron errors are precise to $\sim 2 \%$ before increasing exponentially at count rates $<10000 \mathrm{cps}$, whereas faraday errors are precise to $\sim 1.5 \%$ before exponentially increasing at count rates $<350000 \mathrm{cps}$ (Fig. 6, Electronic Supplement, Table ES1A). As such, the analytical error on each onesecond integration, $\sigma_{s}$, is empirically calibrated from the linearity experiments and proportional to $n_{s}$ on channeltron and faraday detectors, respectively (normalized by a factor of 1.02, the student's $t$ critical value for two-tailed confidence at $68.27 \%(1 \sigma)$ and 29 degrees of freedom):

$\sigma_{s, \text { Channeltron }}=1.02\left(\left(n_{s}+200\right)^{0.42}+0.02\left(n_{s}+200\right)\right)$

and,

$\sigma_{s, \text { faraday }}=1.02\left(\left(n_{s}+100000\right)^{0.5}+0.015\left(n_{s}+100000\right)\right)$

The analytical error on the total counts, $\sigma_{N}$, is then calculated by adding $\sigma_{s}$ to $\sigma_{b g}$ in quadrature for integrations $12-30$ :

$\sigma_{N, \text { Channeltron }}=\sqrt{\sum_{t=12}^{t=30}\left[\sigma_{s, \text { Channeltron }}^{2}+\sigma_{b g}^{2}\right]}$

and,

$\sigma_{N, \text { faraday }}=\sqrt{\sum_{t=12}^{t=30}\left[\sigma_{s, \text { faraday }}^{2}+\sigma_{b g}^{2}\right]}$

Although this method for error propagation cannot detect in-run variability in instrument noise, it does produce a robust estimate of

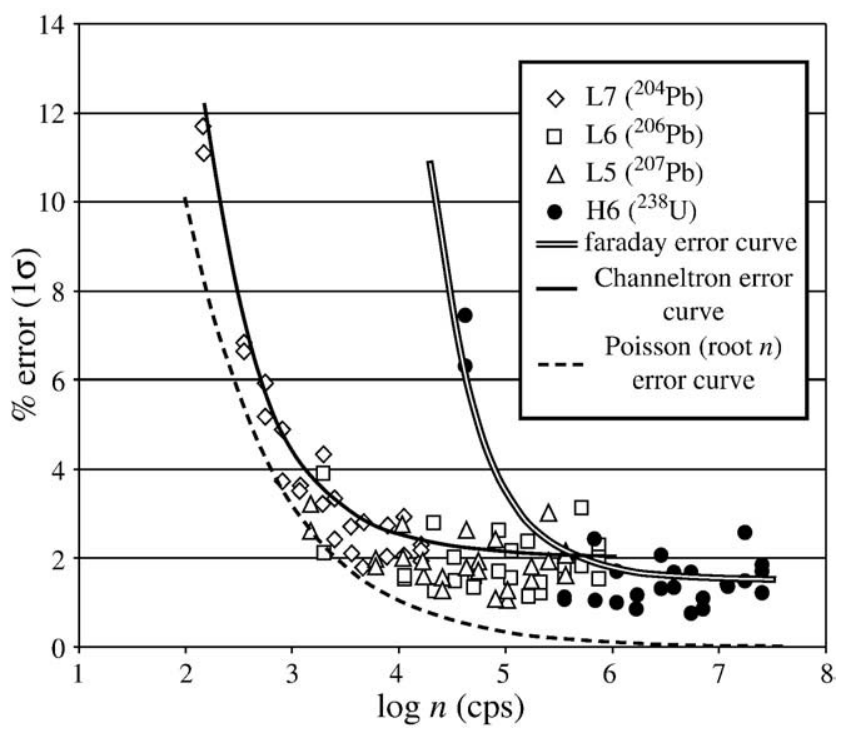

Fig. 6. Relationship between average counts per second (not blank - corrected) and $1 \sigma$ error from sets of 30 one-second integrations measured on Channeltron and faraday detectors throughout the linearity experiments. Also plotted are visual-fit error calibration curves used to calculate errors during laser acquisition; an additional error curve based on root $\mathrm{n}$ is plotted for reference. 
A.

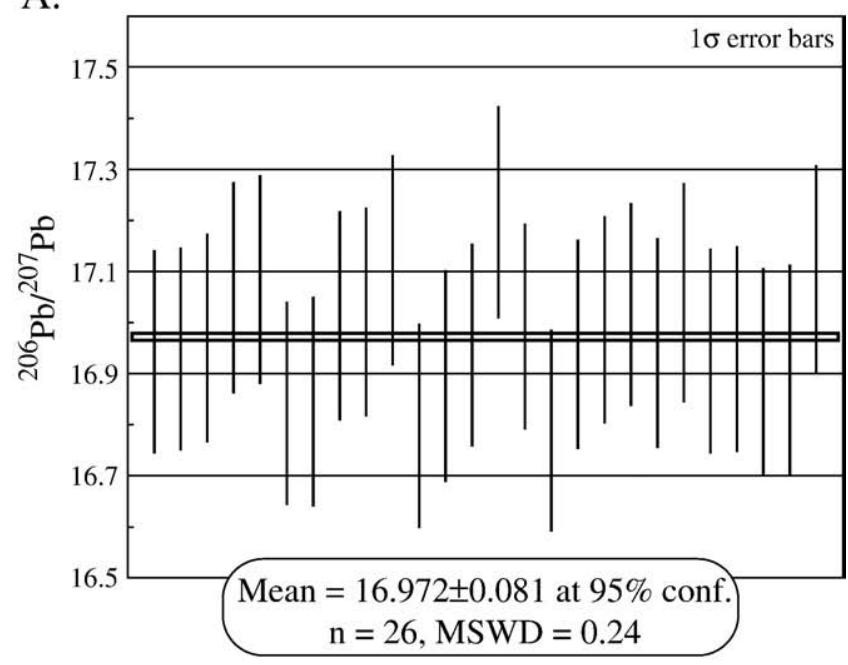

B.

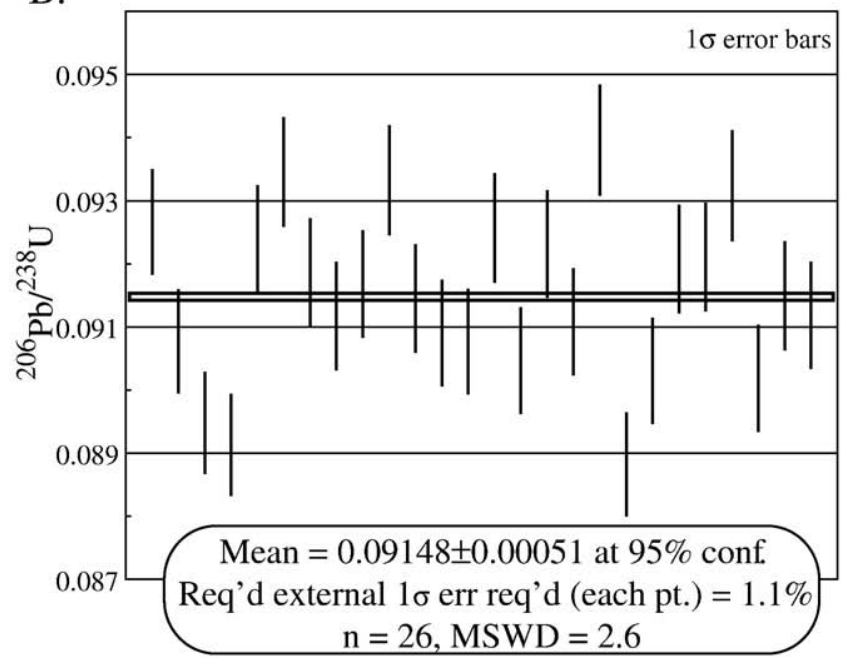

Fig. 7. Fractionation corrected A) ${ }^{206} \mathrm{~Pb} /{ }^{207} \mathrm{~Pb}$ and B) ${ }^{206} \mathrm{~Pb} /{ }^{238} \mathrm{U}$ ratios measured on Sri Lanka Zircon standard throughout the course of the February analysis session using 40 laser pulses shown with measurement errors only. Additional required external error of $1.1 \%$ per analysis on ${ }^{206} \mathrm{~Pb} /{ }^{238} \mathrm{U}$ is interpreted as the result of matrix affects associated with ablation characteristics, depth-dependent mass fractionation combined with minor variations in pit shape, or subtle variations in trace element concentration.

the analytical uncertainty based on the integrated concentration of $U$ and $\mathrm{Pb}$ isotopes in the sample.

Isotope fractionation - the cumulative result of mass fractionation due to variable pit-extraction and ionization efficiency, collector gain and instrument drift - is corrected using fragments of Sri Lanka Zircon (563.5 $\pm 3.2 \mathrm{Ma}$, Gehrels et al., 2008) as a standard that is placed in the sample mount adjacent to unknown grains and analyzed every 4-5 analyses as an external standard. Measured ${ }^{206} \mathrm{~Pb} /{ }^{207} \mathrm{~Pb}$ and ${ }^{206} \mathrm{~Pb} /{ }^{238} \mathrm{U}$ ratios on the standard are compared to the known values and used to generate time-sensitive fractionation curves from which running averages are calculated and applied to ratios from unknown grains (Gehrels et al., 2008). Because the total count integration method used in the smallvolume technique does not make a correction for down-pit variations, $\mathrm{U}-\mathrm{Pb}$ ratios determined by this method are more sensitive to down-pit variations in extraction efficiency than ratios determined by the zero-time intercept method (e.g., Gehrels et al., 2008), and the assumption that standards and unknowns share similar ablation characteristics is particularly important. The propagation of errors through isotope ratios was investigated using fractionation-corrected standard analyses from a typical analysis session (26 analyses on the standard over the course of the entire session). Adding percent errors on $\sigma_{N, 206}$ and $\sigma_{N, 207}$ (calculated as shown above) in quadrature yields a single population with a MSWD $<1$ for the ${ }^{206} \mathrm{~Pb} /{ }^{207} \mathrm{~Pb}$ ratio on standards analyzed throughout the session (Fig. 7A). In contrast, the ${ }^{206} \mathrm{~Pb} /$ ${ }^{238} \mathrm{U}$ ratios on standards from the same analysis session with errors propagated from $\sigma_{N, 206}$ and $\sigma_{N, 238}$ alone, yields a large MSWD that requires an additional $1.1 \%$ error $(1 \sigma)$ for each point (Fig. $7 \mathrm{~B}$, external error after Ludwig, 2003). This data implies that a source of error in addition to the measured errors on ${ }^{206} \mathrm{~Pb}$ and ${ }^{238} \mathrm{U}$ - likely related to either matrix affects associated with ablation characteristics, depth-dependent mass fractionation combined with minor variations in pit shape, or subtle variations in trace element concentration (Black et al., 2004) - is needed to describe the ${ }^{206} \mathrm{~Pb} /{ }^{238} \mathrm{U}$ ratio. As such, and following similar patterns on Sri Lanka Zircon standard ratios from other analysis sessions, analytical errors on the ${ }^{206} \mathrm{~Pb} /{ }^{207} \mathrm{~Pb}$ ratio for each analysis are propagated from $\sigma_{N, 206}$ and $\sigma_{N, 207}$ alone, whereas analytical errors on the ${ }^{206} \mathrm{~Pb} /$ ${ }^{238} \mathrm{U}$ ratio are calculated by adding the measured percent errors on ${ }^{206} \mathrm{~Pb}$ and ${ }^{238} \mathrm{U}$ in quadrature to a user-added external error of $1 \%$.

${ }^{204} \mathrm{~Pb}$ is monitored during analyses, although low common $\mathrm{Pb}$ concentrations in zircon in combination with small-volume analysis typically yields count rates $<50$ cps above background, correspondingly high errors, and values that are not significantly different than zero. During the course of this study, ${ }^{204} \mathrm{~Pb}$ was used primarily to check against the accidental sampling of Pb-rich inclusions or for surface contamination, and a common $\mathrm{Pb}$ correction was not applied to any analyses.

Approximate $U$ and Th concentrations are calibrated by comparing concentrations in the Sri Lanka Zircon (measured by isotope dilution thermal ionization mass spectrometry, ID-TIMS: $\mathrm{U}=518 \mathrm{ppm}, \mathrm{Th}=68 \mathrm{ppm}$, Gehrels et al., 2008) to the average measured signal over the course of the entire session analysis to create $U$ and Th concentration correction factors. These correction factors are then used to generate $U$ and Th concentrations and determine a $\mathrm{U} / \mathrm{Th}$ ratio.

Fractionation corrected ratios, analytical errors, and error correlations are used to calculate ages and assess concordancy. Typically, for single analysis ages (e.g. ages from single grains in a detrital sample), ${ }^{206} \mathrm{~Pb} /{ }^{238} \mathrm{U}$ ages and analytical errors are assigned to analyses $<1.2 \mathrm{Ga}$ and ${ }^{206} \mathrm{~Pb} /{ }^{207} \mathrm{~Pb}$ ages and analytical errors are assigned to analyses older $<1.2 \mathrm{Ga}$. For cogenetic analyses (e.g., zircon analyses interpreted to have shared a common $\mathrm{U}-\mathrm{Pb}$ isotope history), reported ages are weighted averages of either ${ }^{206} \mathrm{~Pb} /{ }^{238} \mathrm{U}$ ages for samples $<1.2 \mathrm{Ga}$ or ${ }^{206} \mathrm{~Pb} /{ }^{207} \mathrm{~Pb}$ ages for samples older $<1.2 \mathrm{Ga}$, whereas all errors are quoted as the $2 \sigma$ standard error on the mean unless stated otherwise. More complicated samples that display significant inheritance or Pbloss are typically assessed using a variety of factors including chemical zoning with respect to $C L$ imaging, $U$ concentration and $U / T h$ ratio, and ages and errors are determined using a combination concordia regressions, weighted averages and the TuffZirc algorithm of Ludwig (2003).

Once an age on a single analysis or group of analyses has been determined, systematic errors associated with the age must be calculated. $2 \sigma$ systematic errors present in the small-volume technique are the result of uncertainty on $U$ decay constants $(0.16 \%$ for $238 \mathrm{U}$ and $0.21 \%$ for $235 \mathrm{U}$, Jaffey et al., 1971; Mattinson, 1987), uncertainty on the age of the external standard (0.57\%, Gehrels et al., 2008), and the average uncertainty on the running average determined through fractionation calibration (usually 1.0-1.5\% depending on the analysis session). These systematic errors are added in quadrature to analytical errors, and yield the final age and total error for the sample. 


\section{Secondary zircon standard results: precision and accuracy}

To test the accuracy and precision of the small-volume technique, a sample mount was made with nine secondary zircon standards with ID-TIMS ages ranging from the Mesoproterozoic-Miocene. From oldest to youngest, analyzed secondary standards include: FC1 (1099.9 Ma, Paces and Miller, 1993), 91,500 (1065 Ma, Wiedenbeck et al., 1995), Peixe (564 Ma, Gehrels, unpublished data), R33 (419.3 Ma, Black et al., 2004), Temora (416.8 Ma, Black et al., 2004), Plesocize (337.1 Ma, Slama et al., 2008), 49127 (136.6 Ma, Mattinson et al., 1986,
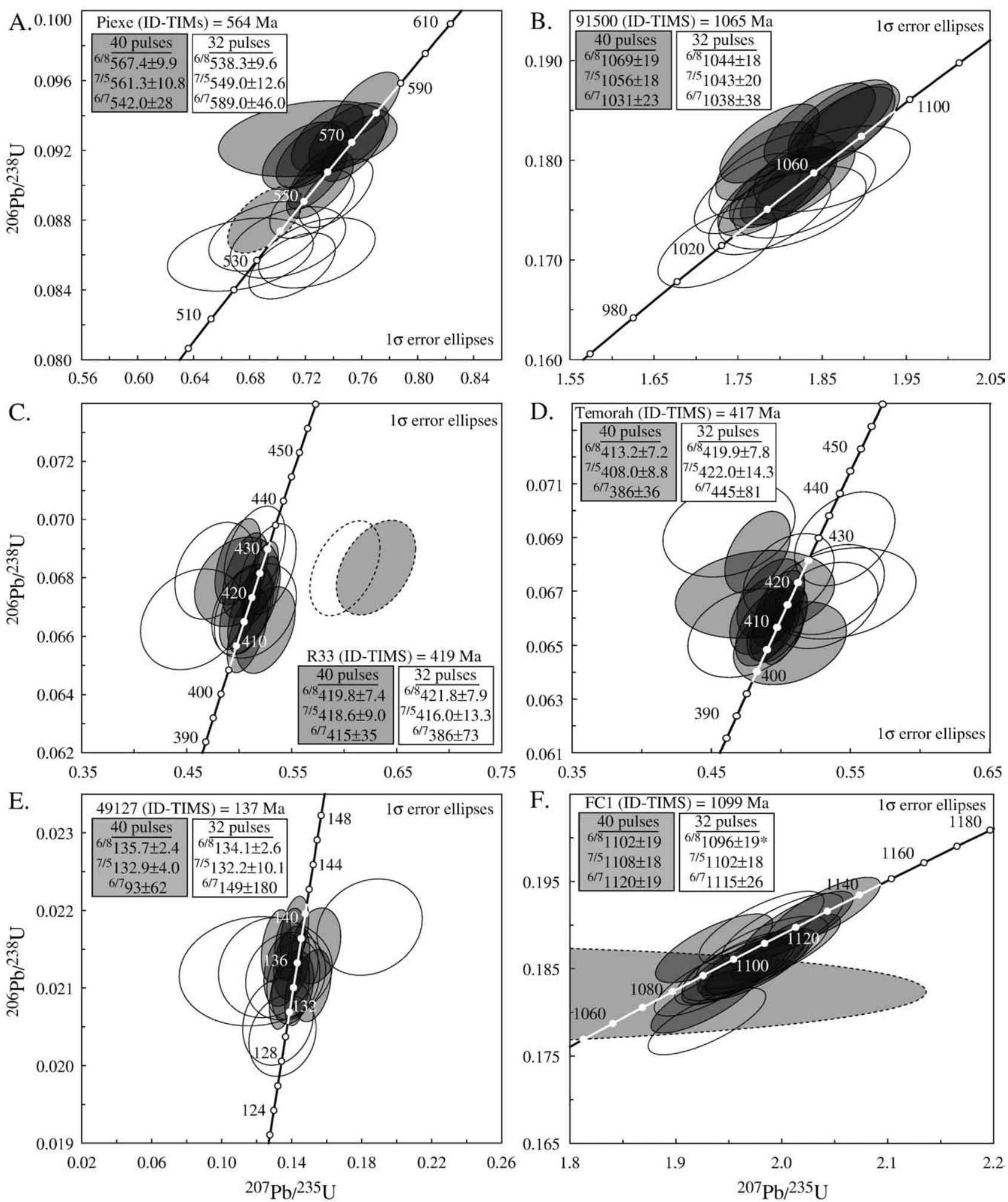

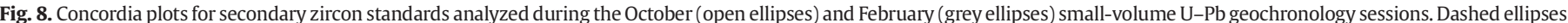

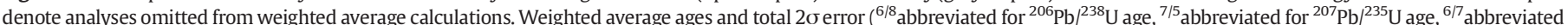

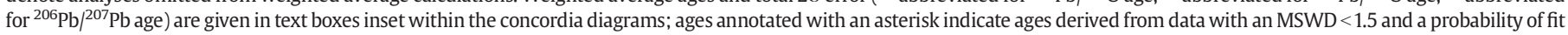
$<0.15$. 

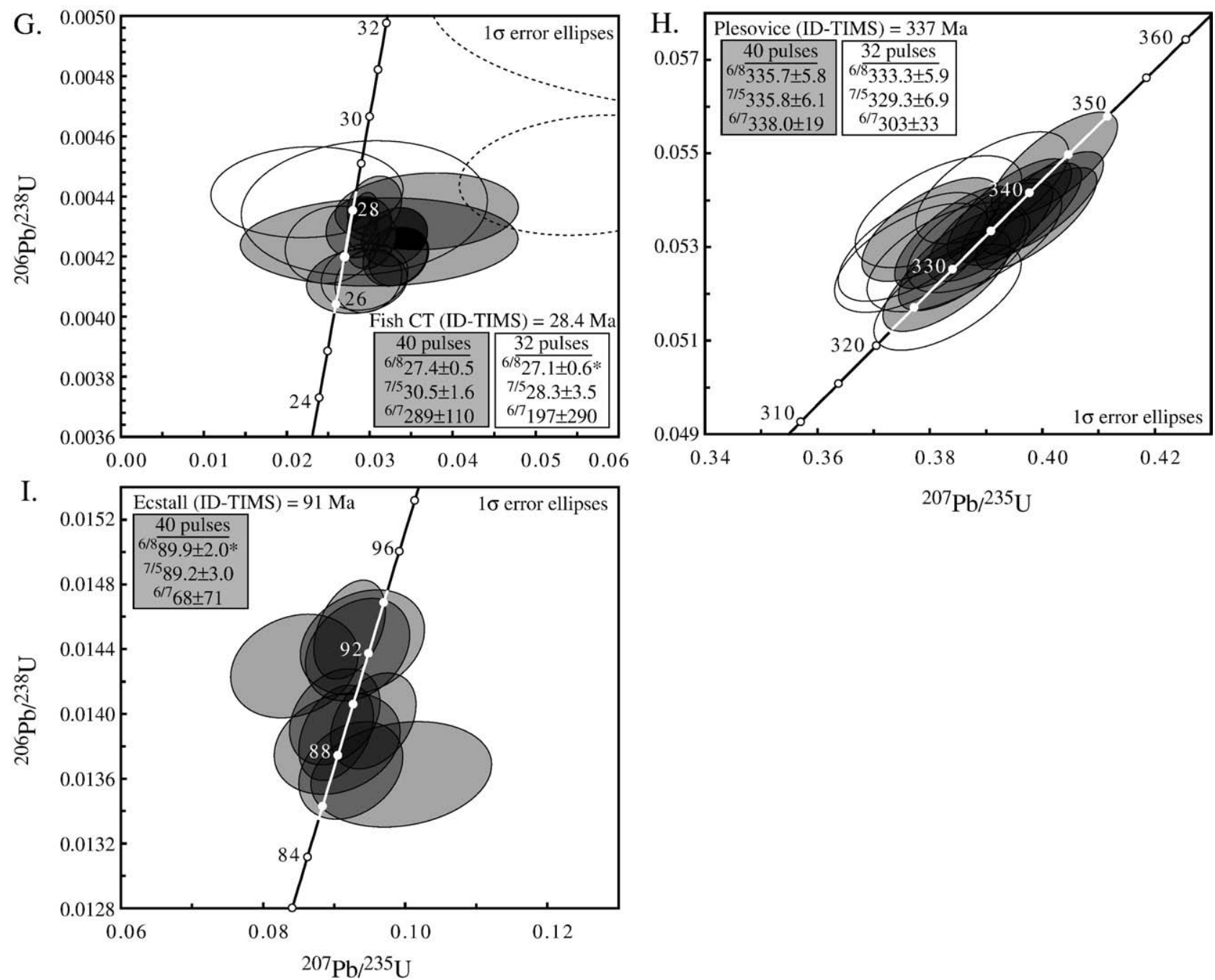

Fig. 8 (continued).

Kimbrough, personal communication), Ecstall (91.5 Ma, Butler et al., 2002), and Fish Canyon Tuff (28.4 Ma without Th correction, Schmitz and Bowring, 2001). Secondary standards were analyzed in two sessions over a period of 4 months: using 7 analyses per sample with 32 laser pulses in October, 2007 and 10 analyses per sample with 40 laser pulses in February, 2008 (Fig. 8, Electronic Supplement, Table ES2). Average ${ }^{204} \mathrm{~Pb},{ }^{206} \mathrm{~Pb}$, and ${ }^{207} \mathrm{~Pb}$ backgrounds from individual analyses measured throughout the two sessions, respectively, were $410 \mathrm{cps}, 2370 \mathrm{cps}$, and 2580 during the October session and $200 \mathrm{cps}$, $990 \mathrm{cps}$, and 1500 cps during the February session; electronic baselines on the two faraday detectors did not change between the two analysis sessions. Background-corrected signals on the zircon samples ranged from $\sim 1700-400000 \mathrm{cps}$ on ${ }^{206} \mathrm{~Pb}$ and from $\sim 100-$ $40000 \mathrm{cps}$ on ${ }^{207} \mathrm{~Pb}$. The fractionation correction factor ranged from $1.62-1.72$ for ${ }^{206} \mathrm{~Pb} /{ }^{238} \mathrm{U}$ and from $1.18-1.26$ for ${ }^{206} \mathrm{~Pb} /{ }^{207} \mathrm{~Pb}$; slightly less variation in the Sri Lanka Standard and the sliding window around the fractionation factor during the October session yields a cumulative systematic error of $1.4 \%$ as opposed to $1.5 \%$ ( $2 \sigma$ standard error on the mean) during the February session.

\subsection{Precision and reproducibility}

In general, analyses from both sessions yield concordant analyses that overlap within error of each other (Fig. 8). Out of
146 total individual analyses, ${ }^{206} \mathrm{~Pb} /{ }^{238} \mathrm{U}$ ages yielded an average $2 \sigma$ analytical error of $2.9 \%$ and an average $2 \sigma$ total error of $3.2 \%$. ${ }^{207} \mathrm{~Pb} /{ }^{235} \mathrm{U}$ ages yielded an average $2 \sigma$ error of $7.7 \%$ and an average $2 \sigma$ total error of $7.9 \%$ (excluding 6 discarded analyses and 3 additional analyses with low ${ }^{207} \mathrm{~Pb}$ ). Combining multiple analyses on the same zircon sample and from the same analysis session yields weighted mean ages with precision significantly better than individual analyses (Table 1). Over the course of both sessions, 6 analyses out of 146 were identified as outliers using either clear discordance or $2 \sigma$ variation from the mean as rejection criterion, and omitted from weighted mean calculations. 8 of 9 samples during the February analysis session with suitable ${ }^{206} \mathrm{~Pb} /{ }^{238} \mathrm{U}$ MSWDs $<1.5$ (high MSWD of 2.6) and 6 of 8 samples that achieved the same level of reproducibility (high MSWD of 2.0) during the October session, indicate that the empirically calibrated useradded external error of $1 \%$ to all ${ }^{206} \mathrm{~Pb} /{ }^{238} \mathrm{U}$ ratios is applicable to a wide variety of zircons. ${ }^{206} \mathrm{~Pb} /{ }^{207} \mathrm{~Pb}$ ratios were consistently reproducible during both analysis sessions with MSWDs ranging from $0.6-1.4$ in February and from $0.5-1.4$ in October (Table 1). Precision on weighted mean ages was slightly better during the February session with an average $2 \sigma$ total error of $1.8 \%$ as opposed to $1.9 \%$ during the October session. It is possible that this improved precision and reproducibility observed in the February session was the result of better sensitivity and increased signal to background 
Table 1

U-Th data and U-Pb ages on secondary zircon standards measured by LA-MC-ICP-MS during both Ocotber and February analysis sessions

\begin{tabular}{|c|c|c|c|c|c|c|c|c|c|c|c|c|c|c|c|c|}
\hline Sample & $\begin{array}{l}\mathrm{U} \\
(\mathrm{ppm})\end{array}$ & $\begin{array}{l} \pm 1 \sigma^{\mathrm{a}} \\
(\mathrm{ppm})\end{array}$ & $\mathrm{U} / \mathrm{Th}$ & $\pm 1 \sigma^{\mathrm{a}}$ & $\begin{array}{l}{ }^{206} \mathrm{~Pb} / \\
{ }^{238} \mathrm{U}^{\mathrm{b}}\end{array}$ & $\begin{array}{l} \pm 2 \sigma \\
(\mathrm{Ma})^{\mathrm{c}}\end{array}$ & $\begin{array}{l} \pm \text { tot. } \\
(\mathrm{Ma})^{\mathrm{d}}\end{array}$ & MSWD & $\begin{array}{l}{ }^{207} \mathrm{~Pb} / \\
{ }^{235} \mathrm{U}^{\mathrm{b}}\end{array}$ & $\begin{array}{l} \pm 2 \sigma \\
(\mathrm{Ma})^{\mathrm{c}}\end{array}$ & $\begin{array}{l} \pm \text { tot. } \\
(\mathrm{Ma})^{\mathrm{d}}\end{array}$ & MSWD & $\begin{array}{l}{ }^{206} \mathrm{~Pb} / \\
{ }^{207} \mathrm{~Pb}^{\mathrm{b}}\end{array}$ & $\begin{array}{l} \pm 2 \sigma \\
(\mathrm{Ma})^{\mathrm{c}}\end{array}$ & $\begin{array}{l} \pm \text { tot. } \\
(\mathrm{Ma})^{\mathrm{d}}\end{array}$ & MSWD \\
\hline \multicolumn{17}{|c|}{ October analysis session: 32 laser pulses/4 $\mu \mathrm{m}$ pits } \\
\hline Peixe & 207 & 92 & 8.6 & 2.58 & 538.3 & 5.9 & 9.6 & 1.40 & 549.0 & 10.0 & 12.6 & 0.86 & 589 & 45 & 46 & 0.55 \\
\hline 91,500 & 109 & 23 & 2.7 & 0.09 & 1044.0 & 11.0 & 18.3 & 0.92 & 1043.0 & 14.0 & 20.2 & 0.72 & 1038 & 35 & 38 & 0.53 \\
\hline R33 & 164 & 49 & 1.4 & 0.18 & 421.8 & 5.3 & 7.9 & 0.77 & 416.0 & 12.0 & 13.3 & 1.06 & 386 & 73 & 73 & 0.94 \\
\hline Temora & 131 & 29 & 2.8 & 0.70 & 419.9 & 5.1 & 7.8 & 1.40 & 422.0 & 13.0 & 14.3 & 1.40 & 445 & 81 & 81 & 1.40 \\
\hline 49,127 & 211 & 60 & 1.1 & 0.09 & 134.1 & 1.8 & 2.6 & 1.50 & 132.2 & 9.9 & 10.1 & 1.13 & 149 & 180 & 180 & 1.11 \\
\hline $\mathrm{FC} 1$ & 529 & 226 & 2.1 & 0.25 & 1096.0 & 11.0 & 18.9 & 2.00 & 1102.4 & 9.8 & 18.3 & 0.50 & 1115 & 20 & 26 & 0.56 \\
\hline Fish CT & 491 & 364 & 2.1 & 0.73 & 27.1 & 0.5 & 0.6 & 2.00 & 28.3 & 3.5 & 3.5 & 0.40 & 197 & 290 & 290 & 0.47 \\
\hline Plesovice & 685 & 110 & 11.6 & 0.61 & 333.3 & 3.6 & 5.9 & 0.95 & 329.3 & 5.1 & 6.9 & 0.38 & 303 & 33 & 33 & 0.65 \\
\hline \multicolumn{17}{|c|}{ February analysis session: 40 laser pulses $/ 5 \mu \mathrm{m}$ pits } \\
\hline Peixe & 173 & 77 & 9.0 & 2.37 & 567.4 & 5.1 & 9.9 & 1.15 & 561.3 & 6.8 & 10.8 & 0.83 & 542 & 27 & 28 & 0.61 \\
\hline 91,500 & 85 & 10 & 2.9 & 0.10 & 1068.8 & 9.2 & 18.5 & 1.30 & 1056.2 & 9.1 & 18.3 & 0.92 & 1031 & 21 & 23 & 0.83 \\
\hline R33 & 148 & 62 & 1.7 & 0.45 & 419.8 & 3.9 & 7.4 & 0.75 & 418.6 & 6.4 & 9.0 & 0.44 & 415 & 35 & 35 & 0.98 \\
\hline Temora & 148 & 82 & 3.2 & 0.75 & 413.2 & 3.7 & 7.2 & 0.90 & 408.0 & 6.3 & 8.8 & 0.23 & 386 & 36 & 36 & 0.89 \\
\hline 49,127 & 262 & 70 & 1.3 & 0.34 & 135.7 & 1.2 & 2.4 & 0.94 & 132.9 & 3.5 & 4.0 & 1.05 & 93 & 62 & 62 & 1.40 \\
\hline $\mathrm{FC} 1$ & 419 & 176 & 2.2 & 0.58 & 1102.2 & 9.1 & 18.9 & 1.40 & 1108.0 & 7.8 & 18.4 & 1.13 & 1120 & 15 & 19 & 0.66 \\
\hline Fish CT & 522 & 277 & 2.2 & 0.95 & 27.4 & 0.3 & 0.5 & 1.20 & 30.5 & 1.5 & 1.6 & 0.70 & 289 & 110 & 110 & 0.98 \\
\hline Ecstall & 335 & 144 & 3.0 & 0.77 & 89.9 & 1.5 & 2.0 & 2.60 & 89.2 & 2.7 & 3.0 & 0.44 & 68 & 71 & 71 & 0.74 \\
\hline Plesovice & 832 & 264 & 10.3 & 1.34 & 335.7 & 2.8 & 5.8 & 0.86 & 335.8 & 3.4 & 6.1 & 1.10 & 338 & 19 & 19 & 0.81 \\
\hline
\end{tabular}

a $\mathrm{U}$ concentration and $\mathrm{U} / \mathrm{Th}$ errors are 1 standard deviation.

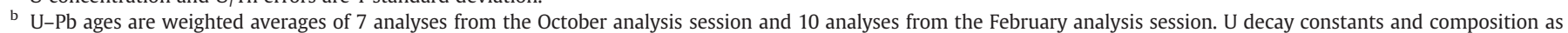
follows: ${ }^{238} \mathrm{U}=9.8485 \times 10^{-10},{ }^{235} \mathrm{U}=1.55125 \times 10^{-10},{ }^{238} \mathrm{U} /{ }^{235} \mathrm{U}=137.88$.

c $2 \sigma$ standard error on the weighted average age accounting for analytical errors only.

d $2 \sigma$ standard error on the weighted average age accounting for analytical errors and systematic errors; accumulated ${ }^{206} \mathrm{~Pb} /{ }^{238} \mathrm{U}$ and ${ }^{206} \mathrm{~Pb} /{ }^{207} \mathrm{~Pb}$ systematic error, respectively, was $1.4 \%$ and $1.5 \%$ during the October analysis session and $1.5 \%$ and $1.0 \%$ during the February analysis session.

levels. However, given the greater reproducibility of the Sri Lanka Zircon standard and the corresponding stability of the fractionation factor during the October session, it is likely that both the greater reproducibility and precision observed in the February session are simply the result of more analyses per sample during that session.

\subsection{Accuracy}

Ages on the nine secondary zircon standards were also generally accurate within their assigned analytical errors with respect to published ID-TIMS ages. Out of the 146 individual analyses, $81 \%$ of ${ }^{206} \mathrm{~Pb} /{ }^{238} \mathrm{U}$ ages were accurate within the calculated $2 \sigma$ total error and $95 \%$ of analyses accurate within $5 \%$, whereas $91 \%$ of analyses yielded ${ }^{207} \mathrm{~Pb} /{ }^{235} \mathrm{U}$ ages were accurate within the calculated $2 \sigma$ total error and $76 \%$ of analyses were accurate within $5 \%$. Plotting the ${ }^{207} \mathrm{~Pb} /{ }^{235} \mathrm{U}$ age offset from the ID-TIMS age for all analyses against average ${ }^{207} \mathrm{~Pb}$ cps during laser acquisition (Fig. 9B) does not reveal any age bias with respect to ${ }^{207} \mathrm{~Pb}$ intensity and suggests that the linearity correction on detector $\mathrm{L} 5\left({ }^{207} \mathrm{~Pb}\right)$ is robust over the range of $\mathrm{Pb}$ concentrations typically observed in zircon. In contrast, a similar plot illustrating ${ }^{206} \mathrm{~Pb} /{ }^{238} \mathrm{U}$ age offset against ${ }^{206} \mathrm{~Pb}$ intensity displays an apparent downward trend in age offsets from 0 to $-4 \%$ over ${ }^{206} \mathrm{~Pb}$ intensities of $10000-2000 \mathrm{cps}$, and indicates that the assumption of Channeltron linearity on detector L6 $\left({ }^{206} \mathrm{~Pb}\right)$ may be compromised in zircons with low ${ }^{206} \mathrm{~Pb}$ yields (Fig. 9A). Weighted mean ages were accurate within $2 \%$ of the published age on 6 of 8 samples during the October session and 8 of 9 samples during the February session; 7 of 9 samples were accurate to $1 \%$ during the February session (Fig. 10A, Table 1). With respect to the calculated total $2 \sigma$ errors, 5 of 8 samples during the October session and 8 of 9 samples during the February session were accurate. The most problematic sample was the Fish Canyon Tuff which yielded ages $4.8 \%$ and $3.6 \%$ (1.3-1.0 Ma) too young in the October and February sessions, respectively, and were also both inaccurate with respect the accepted age and the assigned total $2 \sigma$ errors. These inaccurate ages are likely the result of problems with Channeltron linearity at low intensities. In particular, the increase in ${ }^{206} \mathrm{~Pb} /{ }^{238} \mathrm{U}$ observed in the solution linearity experiments suggests that ${ }^{206} \mathrm{~Pb}$ at low intensities, and thus the ${ }^{206} \mathrm{~Pb}$ backgrounds, were likely overcounted. Although overcounting backgrounds by 3-5\% ( 50$85 \mathrm{cps}$ ) has little effect on zircons with high radiogenic yields, overcounting backgrounds in zircons that yield low ${ }^{206} \mathrm{~Pb}$ intensities could produce erroneously young ages. As such, the young ages observed on the Oligocene-aged Fish Canyon Tuff (yielding $\sim 4700-6800 \mathrm{cps}{ }^{206} \mathrm{~Pb}$ ) suggests a potential limit for the smallvolume $\mathrm{U}-\mathrm{Pb}$ technique to produce precise and accurate ages (at better than $2 \%$ ) in zircons with ${ }^{206} \mathrm{~Pb}$ yields $<\sim 10000 \mathrm{cps}$ until Channeltron linearity on detector L6 is better calibrated at low intensities. During the October session, young and inaccurate ages on Peixe and 91500, the first two samples analyzed, are likely the result of rapid instrument drift after changing the sample mount, and associated with an observed exponentially decaying decrease in backgrounds of $19 \%$ on both ${ }^{206} \mathrm{~Pb}$ and ${ }^{207} \mathrm{~Pb}$ over the first 20 analyses.

\subsection{U-Th concentrations}

$\mathrm{U}$ and Th concentration data from both ID-TIMS and the small-volume technique presented here are extremely variable with standard deviations up to $50 \%$ for U concentrations and up to $40 \%$ for $\mathrm{U} / \mathrm{Th}$ ratios. Despite this large intra-sample variability, average $U$ concentrations and U/Th ratios measured via ID-TIMS and during the course of this study are within $30 \%$ of each other (Fig. 10B, C).

\section{Applications}

\subsection{Detrital zircon provenance of mudstones and shales}

The ability to rapidly collect precise and accurate $(<2 \%) \mathrm{U}-\mathrm{Pb}$ ages on individual zircon grains have brought LA-ICP-MS to the forefront of provenance and sediment dispersal studies which investigate detrital zircon age populations in clastic sedimentary 

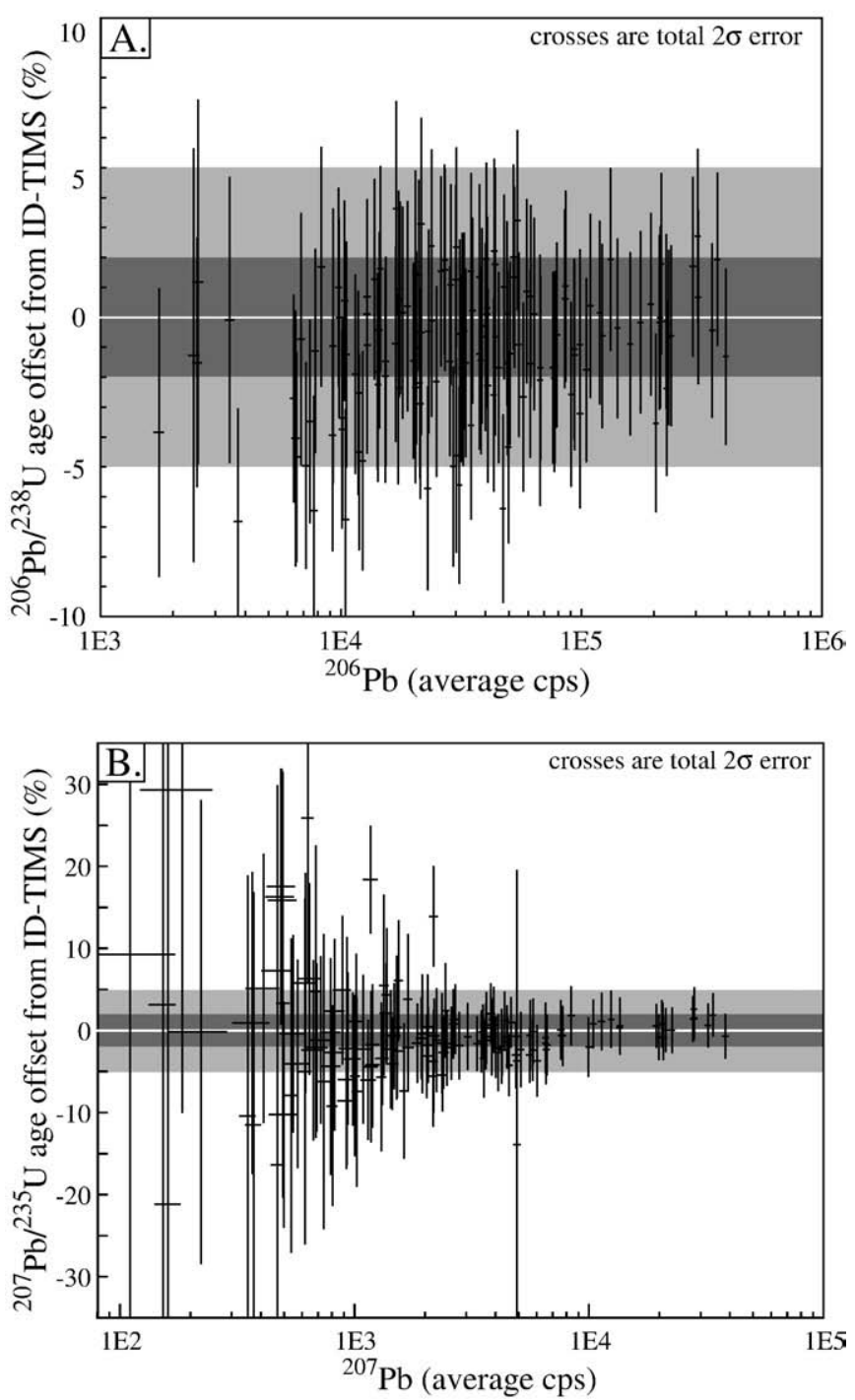

Fig. 9. A) ${ }^{206} \mathrm{~Pb} /{ }^{238} \mathrm{U}$ and B) ${ }^{207} \mathrm{~Pb} /{ }^{235} \mathrm{U}$ age offsets from ID-TIMS for all individual analyses during October and February secondary standard analysis sessions plotted as a function of $\mathrm{Pb}$ concentration. Grey boxes indicate error windows of \pm 2 and $5 \%$.

rocks (Gehrels et al., 2006; Gehrels et al., 2008). In these studies, zircons separated from a sample are selected randomly and individually dated in order to determine a detrital age probability distribution. Age distributions can then be used to determine likely sediment sources, compared to distributions from sediments in adjacent basins to investigate petrogenetic history and sediment dispersal patterns, or used to determine maximum depositional age for the sampled sediment. However, because typical LA-ICP-MS labs use laser spots $25-50 \mu \mathrm{m}$ in diameter and ablate pits $12-20 \mu \mathrm{m}$ deep or raster across the grain surface, detrital zircon studies using LA-ICP-MS have been limited to coarse siltstones and sandstones with grain sizes $<\sim 30 \mu \mathrm{m}$ in diameter. The small-volume technique described here expands the range of grain sizes measurable by LAICP-MS down to fine silts with grain sizes $<\sim 15 \mu \mathrm{m}$, and allows for the routine characterization detrital zircon age populations in siltstones and shales. In a first application of this technique to detrital zircon geochronology, zircons were separated from the Cambrian Bright Angel Shale of the Grand Canyon's Tonto Group. Detrital zircons separated from the Bright Angel Shale range in size from 20-50 $\mu \mathrm{m}$ in diameter and were analyzed using 40 laser pulses with a spot size of $10 \mu \mathrm{m}$. Out of 105 analyses, 17 analyses were discarded due to either extreme discordance or high errors, whereas 88 grains yielded approximately concordant ages ranging from 1.0-2.4 Ga (Fig. 11A, Electronic Supplement, Table ES3A, ES3B). The age probability distribution indicates significant peaks at 1.0, 1.4 and $1.7 \mathrm{Ga}$ with only two Archean grains; including discarded analyses does not significantly alter the distribution (Fig. 11B). This age distribution contains identical age peaks to the Cambrian Tapeats Sandstone (Fig. 11B, Stewart et al., 2001, Gehrels unpublished data), which stratigraphically underlies the Bright Angel Shale, and supports the utility of this technique to accurately characterize detrital zircon age populations.

\section{2. $U-P b$ age mapping of complexly zoned zircon}

One of the primary goals that motivated the development of the small-volume U-Pb geochronologic technique was to investigate $\mathrm{U}-\mathrm{Pb}$ age histories of zircon populations with intricate isotopic zoning at spatial scales $<20 \mu \mathrm{m}$. A granulite-facies pelitic gneiss collected in

A. Age offset from ID-TIMS (\%)
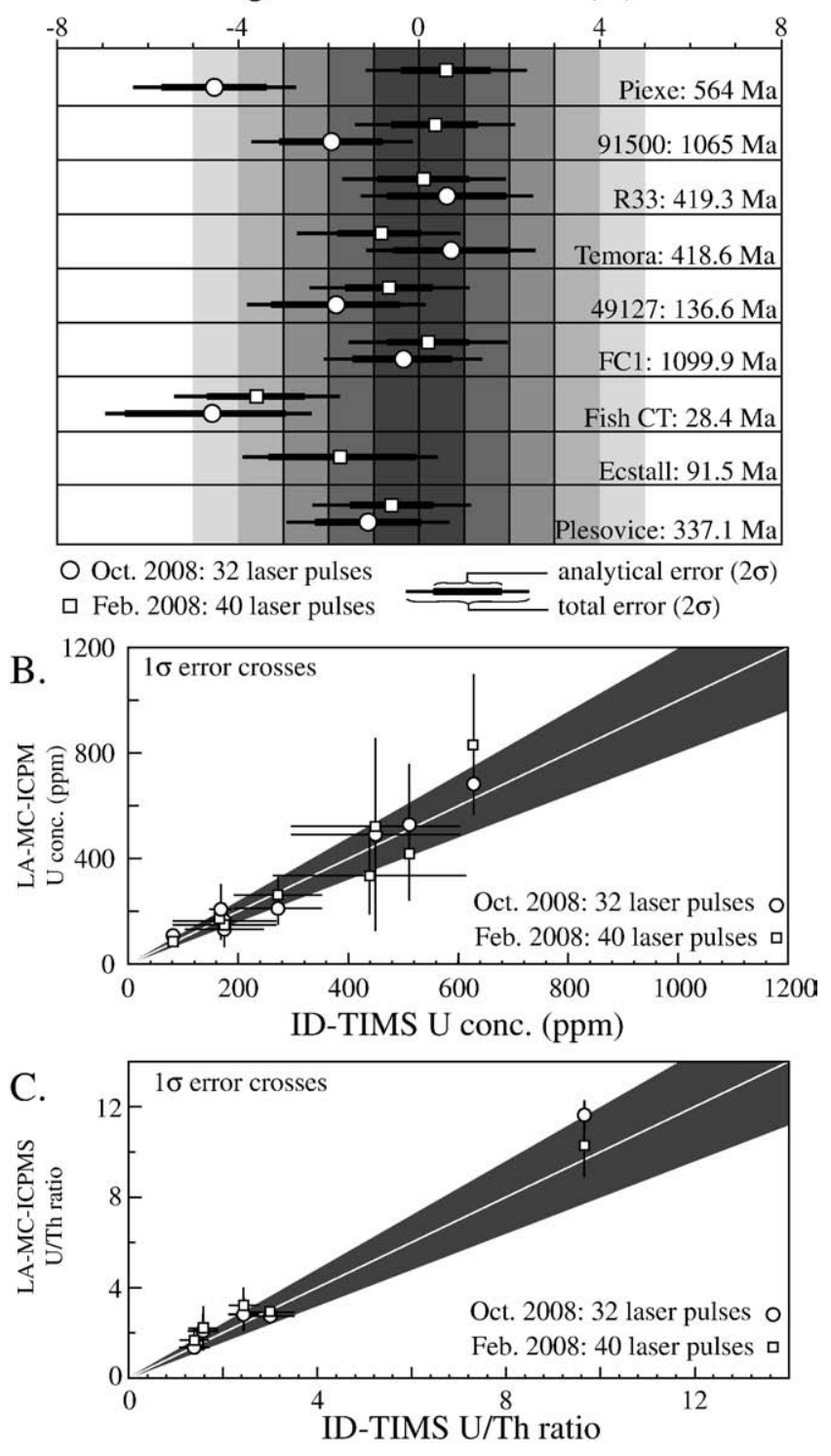

Fig. 10. Comparison of small-volume $\mathrm{U}-\mathrm{Pb}$ geochronology A) age dates, B) U concentrations and $C) U / T h$ values with published ID-TIMS data. Grey areas in $B$ and $C$ represent error windows of $\pm 20 \%$. 

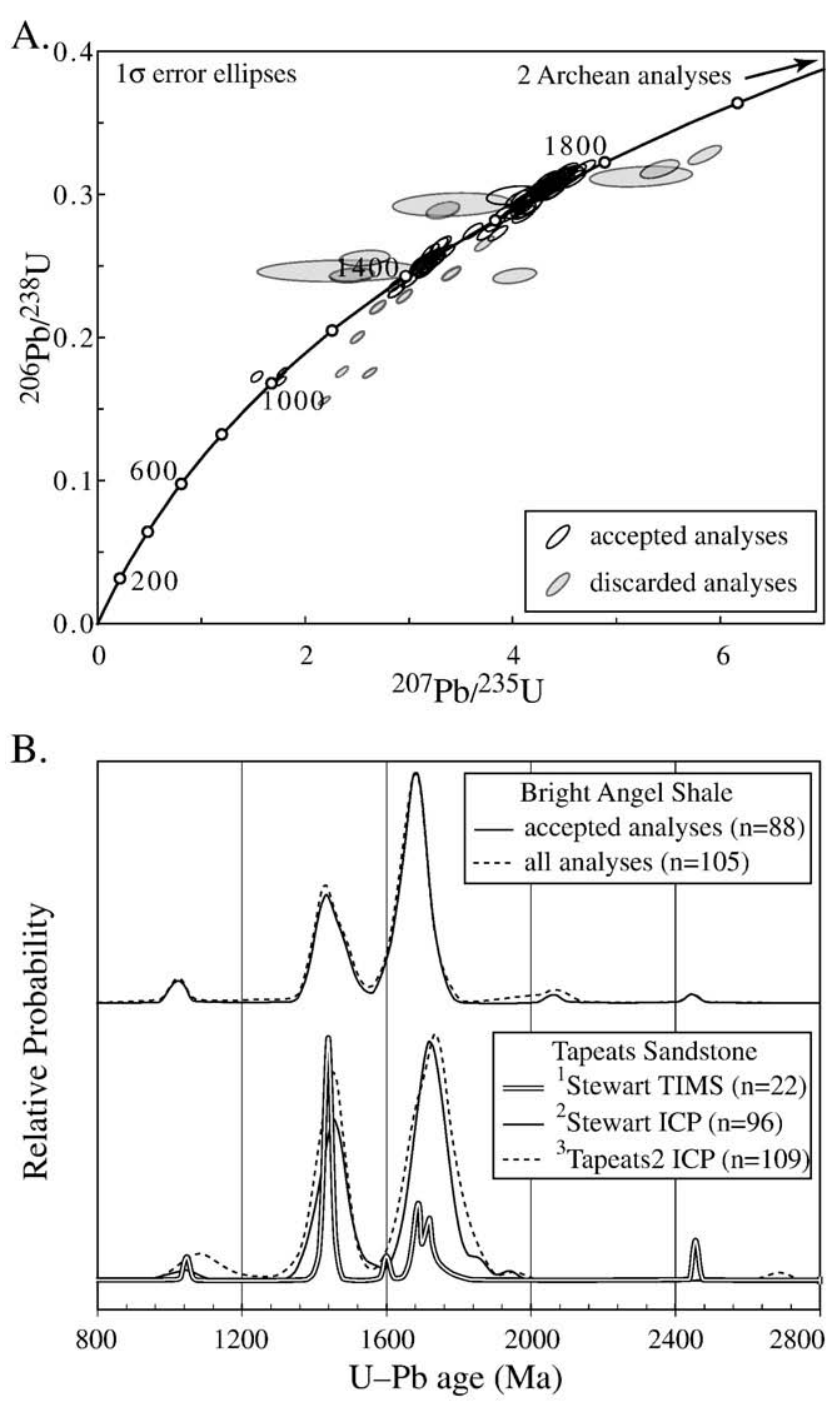

Fig. 11. A) Concordia plot of all analyzed detrital zircons from the Bright Angel Shale B) Detrital zircon age probability distributions from the Bright Angel Shale compared to the distribution from the immediately underlying Tapeats Sandstone $\mathrm{U}-\mathrm{Pb}$ age is ${ }^{206} \mathrm{~Pb} /{ }^{238} \mathrm{U}$ for ages $<1.2 \mathrm{Ga}$ and ${ }^{206} \mathrm{~Pb} /{ }^{207} \mathrm{~Pb}$ for ages $<1.2 \mathrm{Ga}$. Tapeats detrital zircon ID-TIMS data from ${ }^{1}$ Stewart, et al. (2001), and two LA-MC-ICP-MS datasets following the procedure of Gehrels, et al. (2008) from ${ }^{2}$, a repeat of the original Stewart sample and ${ }^{3}$, a second Tapeats Sandstone sample (Gehrels, unpublished data).

Liverpool Land, east Greenland and closely associated with widespread migmatitic textures was selected for a first application of the smallvolume technique to a suite of complicated zircons. With a primary phase assemblage of kyanite+garnet+biotite+plagioclase+K-feldspar, the sample also includes abundant rutile and accessory monazite and zircon. Separated zircons are primarily $30-80 \mu \mathrm{m}$ in diameter with a rounded, colorless and vitreous crystal habit yielding a "beadlike" appearance; $<10 \%$ have yellow-tan cores and are occasionally tabular and up to $100 \mu \mathrm{m}$ in length. CL images of mounted grains display a range of bright and dark cores exhibiting oscillatory through isochemical growth zoning, whereas rims typically $<20 \mu \mathrm{m}$ in width display homogenous $\mathrm{CL}$ response from grain to grain.

To characterize the detrital signature and the timing of hightemperature metamorphism in this sample, 10 grains were selected randomly for $\mathrm{U}-\mathrm{Pb}$ age mapping by the small-volume technique with 32 laser pulses (Electronic Supplement, Table ES4A, ES4B). 2 $\sigma$ systematic error accumulated over the course of the sample session was $1.4 \%$, and 10 analyses on secondary zircon standard R33 measured during the analysis session yield a ${ }^{206} \mathrm{~Pb} /{ }^{238} \mathrm{U}$ age of $424.7 \pm 7.2 \mathrm{Ma}$ (total $2 \sigma$ error and within error of the published ID-TIMS age) and provide a quantitative result supporting the external reproducibility of the analysis session. Working systematically from the rims to the cores in order to avoid contaminating possibly younger rims with ejection debris derived from the cores, between eight and 14 analyses were made in each grain making sure to analyze material from the various chemical domains identified in CL. Plotting all analyses on a concordia diagram yields concordant ages spanning the Archean-Mesoproterozoic with discordant analyses defining a wedge-shaped data field converging toward a lower intercept in the Silurian (Fig. 12A). U/Th ratios are typically $<10$ for core analyses, whereas rim and analyses with ages younger than $\sim 500$ Ma yield higher U/Th ratios up to 126 (Fig. 12A, inset). Calculating upper-intercept ages after Ludwig (2003) from analyses within individual grains yields Model 1 ages ranging from 1180-2840 Ma with age errors that vary from 1-11\% (95\% confidence $+2 \sigma$ systematic error). Under the assumption that all grains grew younger zircon rims at the same time, analyses from all grains with ${ }^{206} \mathrm{~Pb} /{ }^{238} \mathrm{U}$ and ${ }^{207} \mathrm{~Pb} /{ }^{235} \mathrm{U}$ ages $<500 \mathrm{Ma}$ were pooled to calculate a lower-intercept age. ${ }^{206} \mathrm{~Pb} /{ }^{238} \mathrm{U}$ and ${ }^{207} \mathrm{~Pb} /{ }^{235} \mathrm{U}$ ages of $434.7+10.4 /-6.3$ and $433.7+7.9 /-6.8 \mathrm{Ma}(95 \%$ confidence plus $2 \sigma$ systematic error), respectively, were then calculated using the TuffZirc algorithm of Ludwig (2003), designed to identify statistical outliers and calculate ages that are minimally affected by either inheritance or Pb-loss (Fig. 12B). Nine out of the 10 mapped grains, each with cores of different age, yielded at least one analysis that was accepted by TuffZirc and included in the age calculation, and demonstrates the ability of this technique to target specific age domains in intricately zoned crystals. Although the trimmed dataset suggests a minor inherited component on concordia plot (Fig. 12B), the data define a single population and further trimming of the dataset is not warranted given the assigned errors. Archean-Mesoproterozoic detrital zircon ages and a high-temperature Silurian metamorphic event are consistent with detrital signatures and widespread anatexis from 440-425 Ma observed in the Krummedal Group in east Greenland farther west of Liverpool Land (Kalsbeek et al., 2000; Watt et al., 2000; Jones and Strachan, 2000; Kalsbeek et al., 2001; White and Hodges, 2003).

\section{Conclusion}

The small-volume U-Pb geochronology technique at the Arizona LaserChron Center microsamples and dates zircon volumes as small as $12-14 \mu \mathrm{m}$ in diameter by $4-5 \mu \mathrm{m}$ in depth, comparable to sample volumes for $\mathrm{U}-\mathrm{Pb}$ geochronology by secondary ion mass spectrometry (Ireland and Williams, 2003). Low Pb yields produced by the small laser spot diameter and a slow laser pulse rate require using Channeltron detectors to monitor all $\mathrm{Pb}$ peaks coupled with a total count integration counting method to calculate $\mathrm{U}$ and $\mathrm{Pb}$ peaks and isotope ratios. Measurement errors are calculated as a function of the number of counts and observed ${ }^{206} \mathrm{~Pb} /{ }^{238} \mathrm{U}$ scatter on Sri Lanka standard zircon. Using this technique, precise and accurate ages on eight MesoproterozoicCretaceous-aged secondary zircon standards were reproduced within $2 \%$ of published ID-TIMS ages; a ninth Miocene-aged standard produced an age $\sim 1 \mathrm{Ma}$, or $3-4 \%$, too young. In two initial applications of this technique, small-volume $\mathrm{U}-\mathrm{Pb}$ geochronology was used to determine the detrital zircon signature of the Bright Angel Shale and to make $\mathrm{U}-\mathrm{Pb}$ age maps of individual zircons to unravel the detrital-metamorphic history of a granulite-facies paragneiss from east Greenland. In addition to the small spot diameter, the shallow pit depth is essential to the utility of the small-volume technique because it ensures that the sampled volume corresponds directly to chemical zones observed in CL and minimizes the probability that multiple chemical zones will be sampled at greater depths within the sample. The ability of this method to overcome difficulties associated with acquiring meaningful U-Pb ages on complexly zoned zircons by targeting single age domains $<15 \mu \mathrm{m}$, combined with the rapid rate of data collection ( $\sim 60$ analyses per hour) and non-destructive nature of the technique, should prove useful for a 

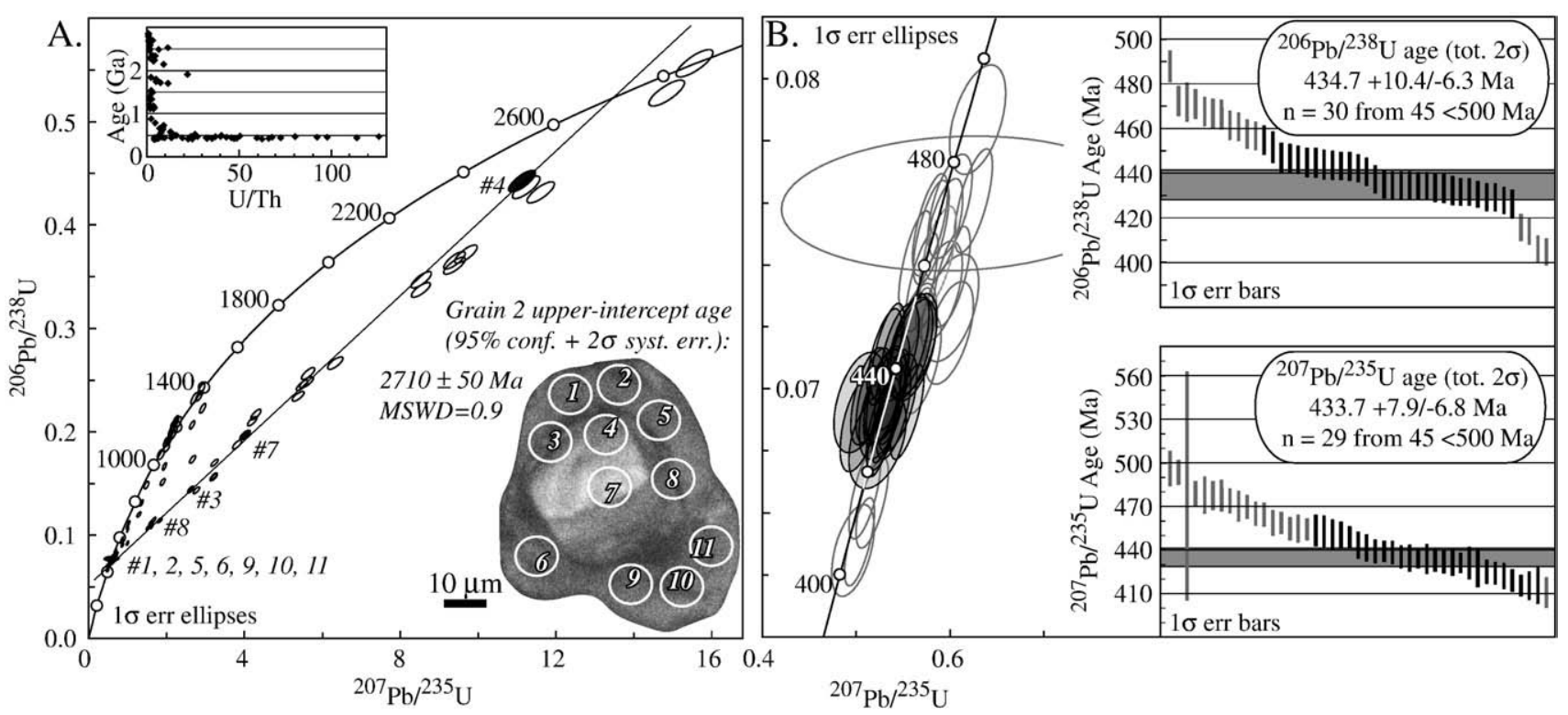

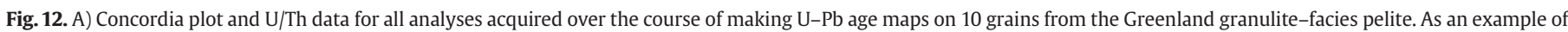

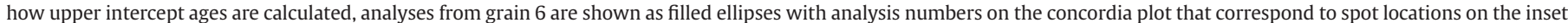

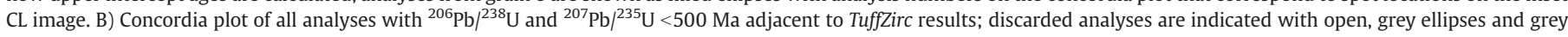
error bars, respectively.

wide variety of geologic applications, and confirms the utility of LA-MCICP-MS as a tool for high spatial resolution $\mathrm{U}-\mathrm{Pb}$ zircon geochronology.

\section{Acknowledgements}

The authors thank Mark Baker and Dave Steinke for many hours of technical assistance keeping the LaserChron lab in excellent condition, and Marty Grove and Alex Pullen for numerous fruitful discussions regarding methods and manuscript presentation. This manuscript also benefitted tremendously from insightful comments by Mark Schmitz and an anonymous reviewer. This work was supported by NSF EAR 0443387 and 0732436.

\section{Appendix A. Supplementary data}

Supplementary data associated with this article can be found, in the online version, at doi:10.1016/j.chemgeo.2008.11.004.

\section{References}

Black, L.P., et al., 2004. Improved $206 \mathrm{~Pb} / 238 \mathrm{U}$ microprobe geochronology by the monitoring of a trace-element-related matrix effect; SHRIMP, ID-TIMS, ELA-ICP-MS and oxygen isotope documentation for a series of zircon standards. Chemical Geology 205, 115-140.

Butler, R.F., Gehrels, G., Baldwin, S.L., Davidson, C., 2002. Paleomagnetism and geochronology of the Ecstall pluton in the Coast Mountains of British Columbia: Evidence for local deformation rather than large-scale transport. Journal of Geophysical Research 107 (B1). doi:10.1029/2001JB000270.

Cherniak, D.J., Watson, E.B., 2003. Diffusion in zircon. Reviews in Mineralogy and Geochemistry 53, 113-144.

Corfu, F., Hanchar, J.M., Hoskin, P.W.O., Kinny, P.D., 2003. Atlas of zircon textures. Reviews in Mineralogy and Geochemistry 53, 469-500.

Fryer, B., Jackson, S., Longerich, H., 1993. The application of laser ablation microprobeinductively coupled plasma-mass spectrometry (LAM-ICP-MS) to in situ (U)-Pb geochronology. Chemical Geology 109, 1-8.

Gehrels, G., Valencia, V.A. Pullen, A., 2006. Detrital zircon geochronology by laserabation multicollector ICPMS at the Arizona Laserchron Center. In: Olszewski, T. (Ed.), Emergin Opportunities, Paleontological Society Short Course. The Paleontological Society, Philadelphia, PA, pp. 67-76.

Gehrels, G., Valencia, V.A., Ruiz, J., 2008. Enhanced precision, accuracy, efficiency, and spatial resolution of U-Pb ages by laser ablation-multicollector-inductively coupled plasma-mass spectrometry. Geochemistry, Geophysics, and Geosystems 9 (3). doi:10.1029/2007GC001805.
Günther, D., Heinrich, C., 1999. Enhanced sensitivity in laser ablation-ICP mass spectrometry using helium-argon mixtures as aerosol carriers. Journal of Analytical Atomic Spectrometry 14, 1363-1368.

Hanchar, J.M., Miller, C.F., 1993. Zircon zonation patterns as revealed by cathodoluminesence and backscattered electron images: Implications for interpretation of complex crustal histories. Chemical Geology 110,1-13.

Ireland, T.R., Williams, I.S., 2003. Considerations in zircon geochronology by SIMS Reviews in Mineralogy \& Geochemistry 53, 215-241.

Jaffey, A.H., Flynn, K.F., Glendenin, L.E., Bentley, W.C., Essling, A.M 1971. Precision measurement of the half-lives and specific activities of U235 and U238. Physical Reviews C 4, 1889-1907.

Jones, K.A., Strachan, R.A., 2000. Crustal thickening and ductile extension in the NE Greenland Caledonides: a metamorphic record from anatectic pelites. Journal of Metamorphic Geology 18, 719-735.

Kalsbeek, F., Jepsen, H.F., Nutman, A.P., 2001. From source migmatites to plutons: tracking the origin of ca. 435 Ma S-type granites in the East Greenland Caledonian orogen. Lithos $57,1-21$.

Kalsbeek, F., Thrane, K., Nutman, A.P., Jepsen, H.F., 2000. Late Mesoproterozoic to early Neoproterozoic history of the East Greenland Caledonides: evidence for Grenvillian orogenesis? Journal of the Geological Society of London 157, 1215-1225.

Kosler, J., Sylvester, P.J., 2003. Present trends and the future of zircon in geochronology: Laser ablation ICPMS. Reviews in Mineralogy \& Geochemistry 53, 243-275.

Ludwig, K., 2003. User's Manual for Isoplot 3.00, A Geochronological Toolkit for Microsoft Excel. Berkeley Geochronology Center Special Publication, vol. 4.

Mattinson, J.M., 1987. U-Pb ages of zircons: A basic examination of error propagation. Chemical Geology (Isotope Geosciences Section) 66, 151-162.

Mattinson, J.M., Kimbrough, D., Bradshaw, J.Y., 1986. Western Fjordland orthgniess: Early Cretaceous arc magmatism and granulite facies metamorphism, New Zealand. Contributions to Mineralogy and Petrology 92, 383-392.

Nasdala, L., et al., 2003. Spectroscopic methods applied to zircon. Reviews in Mineralogy \& Geochemistry 53, 428-467.

Paces, J.B., Miller, J.D.J., 1993. Precise U-Pb ages of Duluth Complex and related mafic intrusions, northeastern Minnesota: Geochronological insights to physical, petrogenetic, paleomagnetic, and tectonomagmatic processes associated with the $1.1 \mathrm{Ga}$ Midcontinent Rift System. Journal of Geophysical Research 98, 13997-14013.

Schmitz, M., Bowring, S.A., 2000. The significance of U-Pb zircon dates in lower crustal xenoliths from the southwestern margin of the Kaapvaal craton, southern Africa. Chemical Geology 172, 59-76.

Schmitz, M.D., Bowring, S.A., 2001. U-Pb zircon and titanite systematics of the Fish Canyon Tuff: an assessment of high precision $\mathrm{U}-\mathrm{Pb}$ geochronology and its application to young volcanic rocks. Geochimica et Cosmochimica Acta 65, 2571-2587.

Slama, J., et al., 2008. Plesovice zircon - A new natural reference material for U-Pb and Hf isotopic analysis. Chemical Geology 249, 1-35.

Stewart, J.H., et al., 2001. Detrital zircon provenance of Mesoproterozoic to Cambrian arenites in the western United States and northwestern Mexico. Geological Society of America Bulletin 113 (10), 1343-1356.

Vavra, G., Gebauer, D., Schmid, R., Compston, W., 1996. Multiple zircon growth and recrystallization during polyphase Late Carboniferous to Triassic metamorphism in granulites of the Ivrea Zone (Southern Alps): an ion microprobe (SHRIMP) study. Contributions to Mineralogy and Petrology 122, 337-358. 
Watt, G.R., Kinny, P.D., Friderichsen, J.D., 2000. U-Pb geochronology of Neoproterozoic and Caledonian tectonothermal events in the East Greenland Caledonides. Journal of the Geological Society of London 157, 1031-1048.

Wetherill, G., 1956. Discordant U-Pb ages. Transactions of the American Geophysica Union 37, 320-326.
White, A.P., Hodges, K.V., 2003. Pressure-temperature-time evolution of the Central East Greenland Caledonides: quantitative constraints on crustal thickening and synorogenic extension. Journal of Metamorphic Geology 21, 875-897.

Wiedenbeck, M., et al., 1995. Three natural zircon standards for U-Th-Pb, Lu-Hf, trace element, and REE analyses. Geostandards Newsletter 19 (1), 1-23. 